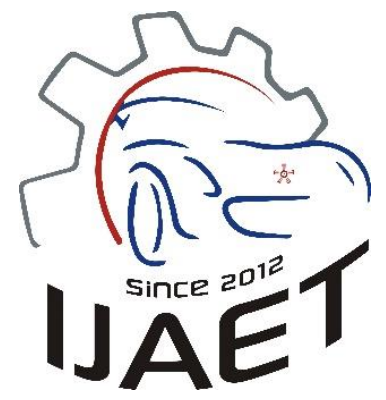

e-ISSN: 2146 - 9067

International Journal of Automotive

Engineering and Technologies

journal homepage: http://ijaet.academicpaper.org

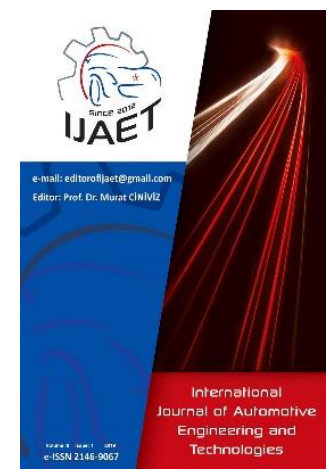

Original Research Article

\title{
Comparative study on the performance of different drive mechanisms used in a beta type Stirling engine through thermodynamic analysis
}

\author{
Derviș Erol ${ }^{1,}$, , Sinan Caliskan ${ }^{2}$ \\ ${ }^{a}$ Kırıkkale University, Department of Automotive Technology, Yahşihan, Kırıkkale, Turkey \\ ${ }^{\mathrm{b}}$ Hitit University, Department of Mechanical Engineering, Çorum, Turkey
}

\begin{abstract}
ARTICLE INFO
* Corresponding author dero140@gmail.com, Tel.: +903183574242

Received: January 25, 2019 Accepted: May 17, 2019

Published by Editorial Board Members of IJAET

(C) This article is distributed by Turk Journal Park System under the CC 4.0 terms and conditions.
\end{abstract}

\begin{abstract}
In this study, thermodynamic and kinematic analyses of bell crank, slider crank, rhombic and scotch yoke drive mechanisms were performed for a beta type Stirling engine with a swept volume of $365 \mathrm{~cm}^{3}$. The kinematic analyses of Stirling engines with these different drive mechanisms were investigated by using the MSC Adams program, and the pressure-volume variations depending on the crankshaft angle were determined by using the isothermal analysis method. It was determined that compression and expansion volume values of rhombic drive mechanism were close to each other, while compression volume value was extremely higher than expansion volume value in other drive mechanisms. For this reason, in this research conducted with working fluid of equal amount $(\mathrm{m}=0.000716 \mathrm{~kg})$, for all of drive mechanisms, it was determined that engine with rhombic drive mechanism generates $19.2 \%$ net work more than the other drive mechanism. The masses of working fluid used in 1 bar charge pressure from engines with bell crank, slider crank, rhombic and scotch yoke drive mechanism were $0.000716 \mathrm{~kg}, 0.000737 \mathrm{~kg}, 0.000536 \mathrm{~kg}$ and $0.000724 \mathrm{~kg}$, respectively. The net work amounts obtained as a result of the thermodynamic analyses made for the 1 bar charge pressure value in bell crank, slider crank, rhombic and scotch yoke drive mechanisms are $12.85 \mathrm{~J}, 12.44 \mathrm{~J}$, $11.61 \mathrm{~J}$ and $13.05 \mathrm{~J}$, respectively. In this research conducted with working fluid in the same charge pressure, it was determined that $10.8 \%$ less net work was obtained from engine with rhombic drive mechanism. Since all the changes of the volume in the bell crank, slider crank and scotch yoke drive mechanisms are very close to each other, the net work performance values obtained with the equal amount of working fluid and the same charge pressure values are also very close to each other.

Keywords: Stirling engines, Bell crank, Slider crank, Rhombic, Scotch Yoke, Thermodynamic analysis
\end{abstract}

\section{Introduction}

The ever-increasing energy need, which has come to the agenda with developing technologies in $21^{\text {st }}$ century, is mostly covered by fossil-based fuels. Extremely harmful emissions are released to the environment in which we live as a result of the use of fossilbased fuels. In addition, it is believed that the reserves of the fossil-based fuels will expire in 
forthcoming years $[1,2]$. The enormous increase in the prices of fossil-based fuels also increases the importance of saving energy. For this reason, scientists are constantly trying to develop machines with low emission release rates to produce power by using alternative energy sources that are cheap and easily available. It is an extremely important criterion that these machines will produce maximum power from the sources they use, and release less emission. Developed countries see the use of alternative energy as the most important way of reducing environmental pollution and energy costs [3-5].

In 1800 s, the water pumps used in coal mines and in quarries operated with steam engines. In those years, it was necessary to develop new and less dangerous engines because the steam engines exploded frequently due to excessive pressure [6]. Robert Stirling developed the hot air engine that was less dangerous when compared with steam engines and had higher productivity by using less fuel [7]. Stirling engines were used to produce mechanical power and electricity for various purposes since the day they were invented. Nowadays, these engines have been brought into the agenda again due to their advantage of producing electricity by using environmental-friendly alternative energy sources [8].

Stirling engines, which are capable of producing power by using any type of alternative energy sources that may be converted into thermal energy like solar energy, come to the forefront when compared with other engines [9].

Air was used as working fluid in the first Stirling engines, and these engines were called "Air engines" $[10,11]$. In forthcoming years, helium, hydrogen, nitrogen and similar gasses were used as working fluid. In the $1950 \mathrm{~s}$, these engines entered the literature by the work of Dr. Roelf Jan Meijer that named as "Stirling engines" in honor of Robert Stirling [12, 13].

Many drive mechanisms have been developed in time by Stirling engine designers for the purpose of ensuring the higher level of the power achieved from the engine, the reduction of the losses that occur due to friction and the increase of the thermal productivity. "Bell crank (Crank rocker)", "Slider crank", "Wobble yoke", "Rhombic drive", "Swash plate", "Scotch yoke", "Ross yoke" and similar drive mechanisms are used in kinematic Stirling engines [8]. Since pistons move in a concentric manner in the same cylinder in beta type Stirling engines, Bell crank, Slider crank, Rhombic drive and Scotch yoke drive mechanisms are preferred in these engines. In beta type Stirling engines, the cycle is performed by concentric power piston and displacer piston that operate in the same cylinder. In such engines, the cylinder volume is divided into two sections, respectively hot and cold volumes through a displacer piston. The hot volume area is in the top part of the displacer piston. In this area, expansion process is obtained by heating the working fluid. For this reason, the hot volume area is also named "Expansion volume". The cold volume area where compression is performed in the volume between the power piston and displacer piston. This area is called "Compression volume" [8].

In an engine without a regenerator, the working fluid between the hot and cold areas passes in a bilateral manner through the void between the displacer piston and the cylinder wall. In engines with regenerators, the flow of the working fluid between the hot and cold areas occurs over the regenerator. Regenerator may be placed on the displacer piston. In a beta type Stirling engine with regenerator, the displacer piston was applied in 1816 by Robert Stirling. The beta type Stirling engines with the regenerator outside the cylinder are called as Rankine-Napier type. In such engines, the dead volume is increased. The heating and cooling processes in beta type Stirling engines may be performed over the cylinder wall as well as over the regenerator [8].

In this study, the performance and thermodynamic analyses were investigated theoretically for the bell crank, slider crank, rhombic and scotch yoke drive mechanisms in the same conditions for a beta type Stirling engine with a swept volume of $365 \mathrm{~cm}^{3}$. The kinematic analyses of the Stirling engine with these different drive mechanisms were made by using the MSC Adams program. The changes in the volume and pressure due to the crank angle of the engines with bell crank, slider crank, rhombic and scotch yoke drive mechanisms were determined by using the isothermal analysis method. The net work amounts obtained within one cycle time were computed 
as a result of thermodynamic analyses. The effects of working fluid mass, charge pressure and heater temperatures on the net work amount were also investigated for each drive mechanism. The results of these drive mechanisms performance characteristics were compared with each other in graphics. This study provides to designers and researchers who work in the field of Stirling engines detailed data on the more efficient drive mechanism for a beta type Stirling engines. In addition, the new results obtained in the present study offer, a wide analysis opportunity for designers and researchers.

\section{Thermodynamic analyses of drive mechanisms used in beta type Stirling engines}

Kinematics investigates the movements of objects without considering the masses and the forces that are effective on them. The parameters such as cyclic work, pressure and volume of an existing system and the performance properties may be determined with the thermodynamic analysis method before the production of prototypes are made. Thermodynamic analysis has an important place in engine design.

MSC Adams (Automatic Dynamic Analysis of Mechanical System) Program is one of the dynamic and kinematic analysis software used commonly all over the world. This program was developed by Microsoft Software Corporation. MSC Adams program is an extremely developed software that may perform dynamic and kinematic analyses of mechanical systems using a computer medium through virtual testing prototypes just like in real life situations. With this program, the design quality of systems is increased, and important reductions are obtained in the costs of designs and prototypes $[49,50]$.

The kinematic analyses of Stirling engines with bell crank, slider crank, rhombic drive and scotch yoke drive mechanisms were performed using the MSC Adams program. In MSC Adams program, only volumetric changes for Stirling engines with bell crank, slider crank, rhombic, and scotch yoke drive mechanisms were determined for each degree of the crankshaft. Thermodynamic analyses were performed using these values. Moreover, the characteristic values of different drive mechanisms used in beta-type Stirling engines enabled the researchers to get a better idea with the help of animated video images created in Adams program. The drawings and montages of the models used in MSC Adams program were made in the SolidWorks program, which is one of the CAD programs.

With the isothermal analysis method, which was developed by Gustav Schmidt in 1871, the performance parameters of an existing system like pressure, volume and power may be determined theoretically before the engine prototypes are produced. In this analysis method, all of heat and friction losses occurring in the Stirling engine are neglected. Therefore, in the analyses, temperatures of the gas masses in expansion volume, compression volume and regenerator are taken as equal to the internal wall temperatures. The equations used in determining the changes in net work and pressure obtained from Stirling engines are given in Equations (1-2).

Pressure in isothermal analysis,

$P=m \cdot R\left(\frac{V_{1}}{T_{1}}+\frac{V_{2}}{T_{2}}+\ldots . .+\frac{V_{n}}{T_{n}}\right)^{-1}$

Where $\mathrm{P}$ is the pressure (Bar), $\mathrm{m}$ is the mass of the working fluid $(\mathrm{kg}), \mathrm{R}$ is the gas constant $(\mathrm{J} / \mathrm{kgK}), \mathrm{T}$ is the temperature $(\mathrm{K})$ and $\mathrm{V}$ is the volume $\left(\mathrm{cm}^{3}\right)$.

Net work,

$W=\sum_{i=1}^{i=k} P_{i}\left(V_{i}-V_{i-1}\right)$

Where $\mathrm{W}$ is the work ( $\mathrm{J} /$ cycle) .

equations are used.

The bell crank, slider crank, rhombic and scotch yoke drive mechanisms are used due to the fact that the pistons of beta type Stirling engines act in the same cylinder in a concentric manner. The technical properties of the engine whose thermodynamic analysis is made for these drive mechanisms are given in Table 1. These technical properties were considered the same for each drive mechanism. Only the drive mechanism types of the engine were changed during the analyses.

Many theoretical and experimental studies were conducted in the literature by researchers on these four different drive mechanisms used in 
beta type Stirling engines. The technical properties of these theoretical and experimental studies are given in Table A.1. The fact that all the real events happening in engines are complex, has driven researchers to conduct theoretical analyses. The production of a prototype of Stirling engines is a high-cost process that requires too much time. The working parameters of the engine are determined by conducting numerical analyses before the actual production of the prototype. For this reason, firstly, theoretical and numerical analyses are conducted in the research phase. According to the results of theoretical analyses, the prototype of the engine is produced, and the results are compared with the results of the experimental research. The isothermal analysis method used in the design analyses of Stirling engines were developed in 1871 by Gustav Schmidt, and the Nodal analysis method was developed by Theodor Finkelstein [14-16].

Table 1. Technical properties of the engine whose thermodynamic analysis was made

\begin{tabular}{ll}
\hline Parameters & Specifications \\
\hline Engine type & Beta \\
Swept volume $\left(\mathrm{cm}^{3}\right)$ & 365 \\
Displacer cylinder bore $(\mathrm{mm})$ & 88 \\
Displacer piston bore $(\mathrm{mm})$ & 87 \\
Displacer piston stroke $(\mathrm{mm})$ & 60 \\
Power cylinder bore $(\mathrm{mm})$ & 88 \\
Power piston bore $(\mathrm{mm})$ & 88 \\
Power piston stroke $(\mathrm{mm})$ & 60 \\
Working fluid & Air \\
Coolant temperature $(\mathrm{K})$ & 300 \\
\hline
\end{tabular}

Bell crank drive mechanism is a simple intermediary tool used to change the direction of the movement. The input and output direction of the movement is different nearly at a rate of $90^{\circ}$. Bell crank mechanisms may be used in many machine systems for various purposes, such as for converting the linear movement into a circular one $[17,18]$. Bell crank drive mechanism is the first mechanism used for Stirling engines. Bell crank drive mechanism is more suitable for small engines with one single cylinder. In engines with this mechanism, the pressure in the crankcase must be close to the atmospheric pressure at the minimum level. Increased charge pressure causes the reduction of the engine power. It is not preferred in bigger engines because of its weight. In this drive mechanism, the lateral friction that occurs between the displacer piston rod and power piston is higher than the others, which causes the reduction of the engine power. A beta type Stirling engine with bell crank drive mechanism was designed by the Philips Company in 1951, and the engine was produced. This engine was successfully applied to the generator called Philips Bungalow Set (MP1002CA). It was reported that $200 \mathrm{~W}$ electricity was obtained from this generator $[19,20]$. Karabulut et al. made thermodynamic analyses and experimental studies of the newly developed bell crank drive mechanism and rhombic drive mechanism for a beta type Stirling engine as well as compared the results obtained from such studies [21, 22]. The schematic drawing of a Stirling engine with bell crank drive mechanism, created in MSC Adams software and developed for analyses is given in Fig. 1-a. Slider crank drive mechanisms are used frequently in many machine systems like internal combustion engines, steam engines, pumps and compressors. Since the invention of internal combustion engines, the slider crank drive mechanism has been used successfully in these engines, and are still being preferred today. The most important advantages of this mechanisms are the fact that they are produced easily and have low costs when compared with other drive mechanisms [18, 23-26]. In such mechanisms, the lateral friction forces that occur between the power piston and cylinder, and between the displacer piston rod and power piston are extremely high. These lateral forces reduce the power of the engine. In addition, the difficulty in achieving a balance in these engines is one of the drawbacks of them. Since the simple two-cylinder Stirling engine minimizes the balance problem, it may also be preferred. The schematic drawing of the Stirling engine with Slider crank drive mechanism created in MSC Adams software is given in Fig. 1-b. Çınar C. et al. designed and produced a beta type Stirling engine with slider crank drive mechanism and with $192 \mathrm{~cm}^{3}$ swept volume. Tests with air as working fluid measured a maximum engine power of $5.98 \mathrm{~W}$ at $208 \mathrm{rpm}$ with $1000{ }^{\circ} \mathrm{C}$ heater temperature [27]. Cheng et al. investigated the thermal efficiency in a Stirling engine with beta type slider crank drive mechanism by using a numerical model, and designed the engine by making the theoretical analyses [28]. Araoz et al. investigated 
theoretically the numeric simulation that included all of the thermodynamic, thermal and mechanical interactions of a Stirling engine with slider crank drive mechanism, and compared the results with experimental analyses [29]. Barreto et al. analyzed theoretically the dynamic simulation and optimization of a beta type Stirling engine with slider crank drive mechanism that run with solar energy by using a parabolic aerial, and investigated the effects on engine performance [30].

Rhombic drive mechanism was first applied to Stirling engines in 1953 by the Philips Company. This mechanism is used for the purpose of reducing the engine size, decreasing mechanical connections, and minimizing the reduction in efficiency that occur due to friction and mechanical losses. Rhombic drive mechanism consists of a crankshaft rotated in a balanced manner and a rod mechanism rotated in the opposite directions joined with two synchronized gears. The displacer piston, power piston, connection parts, connection rods and time adjustment gears are connected to each other to work in concordance. The power piston rod is connected to the top connection part, and the displacer piston rod is attached to the bottom connection part. The power piston and the displacer piston work with simple harmonic motion. The most important advantage of this mechanism is that the lateral friction forces that occur between the displacer piston rod and power piston are very low. If the lateral friction forces are low, the corrosion that might occur on the parts will be reduced, and the power and torque will be increased $[8,31]$. The schematic drawing of the Stirling engine with rhombic drive mechanism created in MSC Adams software is given in Fig. 1-c. Eid E. conducted a theoretical research by using the analysis that was developed by Gustav Schmidt on a Stirling engine with rhombic drive mechanism. In this study, the heater, cooler, regenerator and the power and displacer stroke were accepted as non-dimensional, and the optimum working conditions were determined [32]. Cheng et al. have conducted many theoretical and experimental studies on beta type Stirling engines since 2010. Cheng et al. conducted theoretical analyses of a Stirling engine with rhombic drive mechanism for the purpose of obtaining $300 \mathrm{~W}$ power. In experimental studies,
390W power was obtained at $1400 \mathrm{rpm}$ at $850^{\circ} \mathrm{C}$ heater temperature at 8 bar charge pressure by using regenerator [33-36]. Cheng et al. conducted theoretical analyses of two different Stirling engines with rhombic drive mechanism to obtain $500 \mathrm{~W}$ and $1 \mathrm{~kW}$ output power from a beta type Stirling engine; and the prototypes of these engines were produced. They investigated the thermal and numerical analyses for the engine with $1 \mathrm{~kW}$ power by using different working fluids with the help of the Computational Fluid Dynamics (CFD) Program $[37,38]$. Shendage et al. compared theoretical analyses rhombic drive mechanism and slider crank drive mechanism in a Stirling engine. They reported that the Stirling engine with rhombic drive mechanism produced $10 \%$ more power than the slider crank drive mechanism [39]. Karabulut et al. investigated the performance properties of a beta type Stirling engine with rhombic drive mechanism and an engine with bell crank drive mechanism in a theoretical manner [40]. Aksoy et al. compared the effects of rhombic drive mechanism and slider crank drive mechanism in a beta type Stirling engine on engine performance in a theoretical study [41].

Scotch yoke drive mechanisms were designed by Charles Algernon Parsons. Scotch yoke drive mechanism is a simple mechanism that is used to convert the linear movement of pistons into circular movement by using minimum parts. In later years, scotch yoke drive mechanisms were developed and their perfect balancing was achieved by using simple harmonic movements of the mechanism that was designed by Parsons $[8,18]$. Scotch yoke drive mechanisms are generally used in the valve mechanisms of highpressure oil and gas pipe lines. In addition, they are also preferred in many mechanical systems that have a wide usage area, such as SyTech engine and Bourke engine, which are internal combustion engines. They are also used in some steam engines [42-44]. The most important advantage of this mechanism is the fact that the lateral friction forces that occur between the displacer piston rod and power piston are extremely low at such a point that might be ignored when compared with the bell crank and slider crank mechanisms. In this way, the reduction of lateral friction forces, reduces the corrosions that might occur in some parts. 
Because of all these reasons, scotch yoke drive mechanism increases the power and torque of the engine. The Schematic drawing of a Stirling engine with Scotch yoke drive mechanism obtained in MSC Adams software is given in Fig. 1-d. Iwamoto et al. designed and produced a low temperature differential Stirling engine with Scotch yoke drive mechanism. It was reported that $300 \mathrm{~W}$ output power could be obtained with this engine in the trials conducted at $100^{\circ} \mathrm{C}$ heater temperature $[45,46]$. Hirata et al. designed and produced a Stirling engine with scotch yoke drive mechanism, which was called Ecoboy-SCM81. During the trial performed with this Stirling engine, by using helium as working fluid the power obtained at $700^{\circ} \mathrm{C}$ heater temperature in $0.8 \mathrm{MPa}$ charge pressure
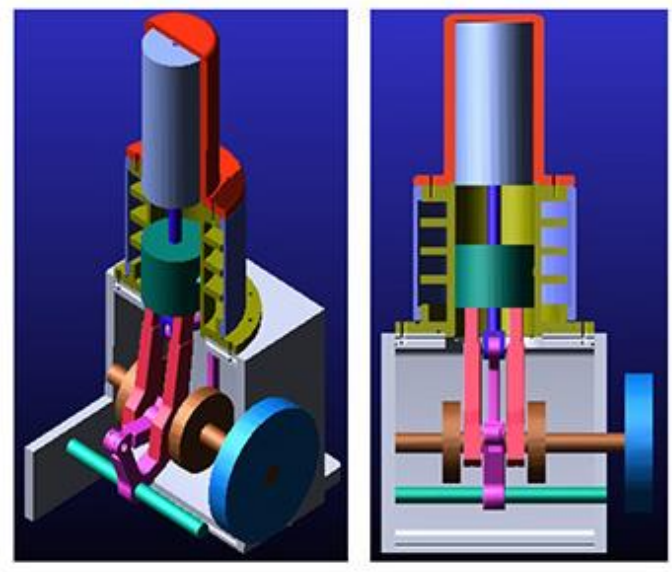

(a)

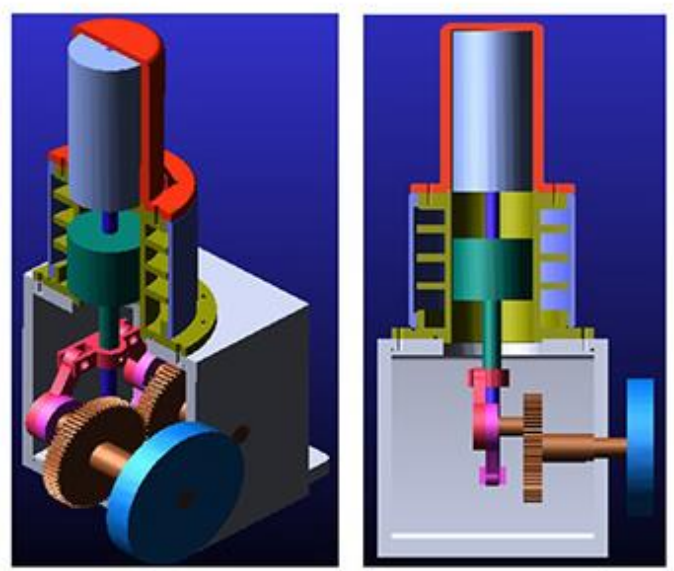

(C) at $1300 \mathrm{rpm}$ was 74W [47]. Sripakagorn et al. produced a Stirling engine with scotch yoke drive mechanism which could work at relatively lower temperatures. The trials were performed in this newly produced Stirling engine, by using air as the working fluid, reported that $95.4 \mathrm{~W}$ power was obtained at $500^{\circ} \mathrm{C}$ heater temperature under 7 bar charge pressure at $360 \mathrm{rpm}$ [48].

When Table A.1 was examined, it is obvious that the comparison of the effects of bell crank, slider crank, rhombic drive and scotch yoke drive mechanisms on engine performance isn't studied in the literature on beta type Stirling engines. For this reason, the lack of comparison of different drive mechanisms used in beta type Stirling engines makes our study extremely important for the literature.
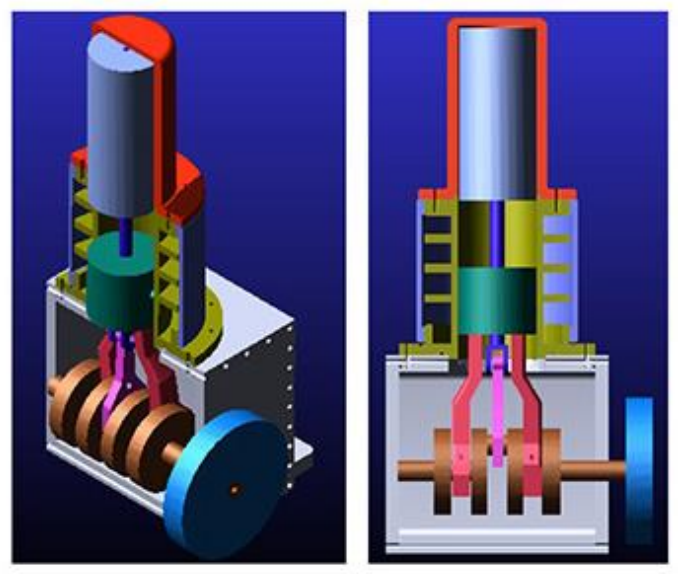

(b)
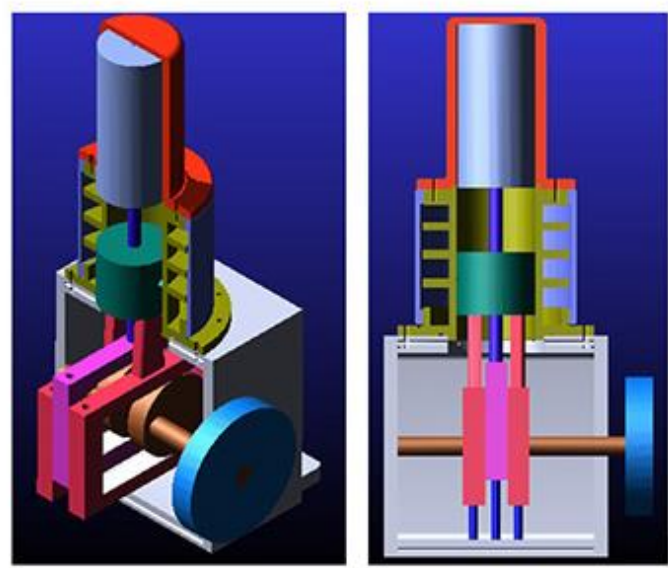

(d)

Fig. 1. Schematic drawings of Stirling engine with bell crank, slider crank, rhombic and scotch yoke drive mechanisms

\section{Results and Discussion}

Comparison of $\mathrm{P}-\mathrm{V}$ diagrams at different heater temperatures, depending on volume change of Stirling engine with bell crank drive mechanism is given in Fig. 2. During the thermodynamic analyses the mass of the working fluid was kept constant at $0.000716 \mathrm{~kg}$ and coolant temperature was kept constant at $300 \mathrm{~K}$. Air was used as the working fluid in thermodynamic analyses. Cyclic work values of this engine with bell crank drive mechanism were calculated as 11.73 $\mathrm{J}, 12.85 \mathrm{~J}, 13.81 \mathrm{~J}, 14.65 \mathrm{~J}$ and $15.38 \mathrm{~J}$, for 
different heater temperature, respectively. The net work values are obtained from Eq. (2).

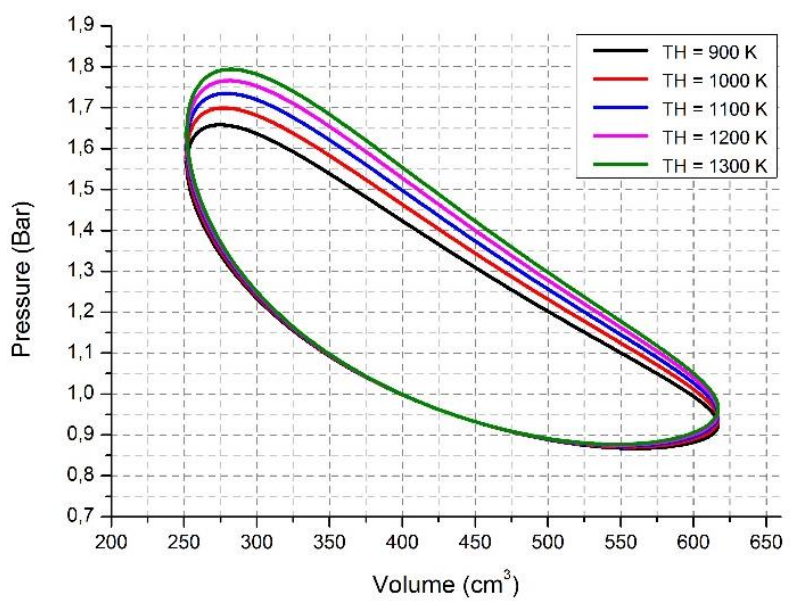

Fig. 2. Comparison of $\mathrm{P}-\mathrm{V}$ diagrams for different temperatures of bell crank drive mechanism

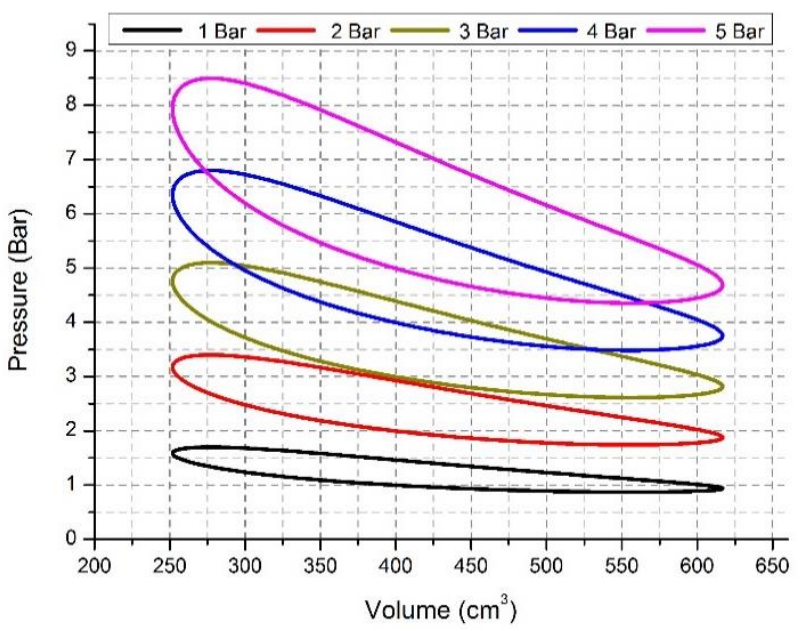

Fig. 3. Comparison of $\mathrm{P}-\mathrm{V}$ diagrams for different charge pressures of bell crank drive mechanism

Comparison of $\mathrm{P}-\mathrm{V}$ diagrams at different charge pressures, depending on volume change of Stirling engine with bell crank drive mechanism is given in Fig. 3. The mass of the working fluid varies at a certain rate as the amount of charge pressure increases. The heater temperature and the coolant temperature were kept constant respectively $1000 \mathrm{~K}$ and $300 \mathrm{~K}$ during a cycle for 1, 2, 3, 4, and 5 bar charge pressures. Under these conditions, cyclic work values of this engine with bell crank drive mechanism were obtained as $12.85 \mathrm{~J}, 25.70 \mathrm{~J}, 38.55 \mathrm{~J}, 51.40 \mathrm{~J}$ and $64.25 \mathrm{~J}$, respectively. When the graphic and results are examined, it is determined that the net cyclic work amount performed increases in direct proportion to the charge pressure.

Comparison of $\mathrm{P}-\mathrm{V}$ diagrams at different heater temperatures, depending on volume change of Stirling engine with slider crank drive mechanism is given in Fig. 4. During the thermodynamic analyses the mass of the working fluid was kept constant at $0.000737 \mathrm{~kg}$ and coolant temperature was kept constant at $300 \mathrm{~K}$. Cyclic work values of this engine with slider crank drive mechanism were calculated as $11.34 \mathrm{~J}, 12.44 \mathrm{~J}, 13.38 \mathrm{~J}, 14.21 \mathrm{~J}$ and $14.92 \mathrm{~J}$, for different heater temperature, respectively. The net work output is thus obtained from Eq. (2).

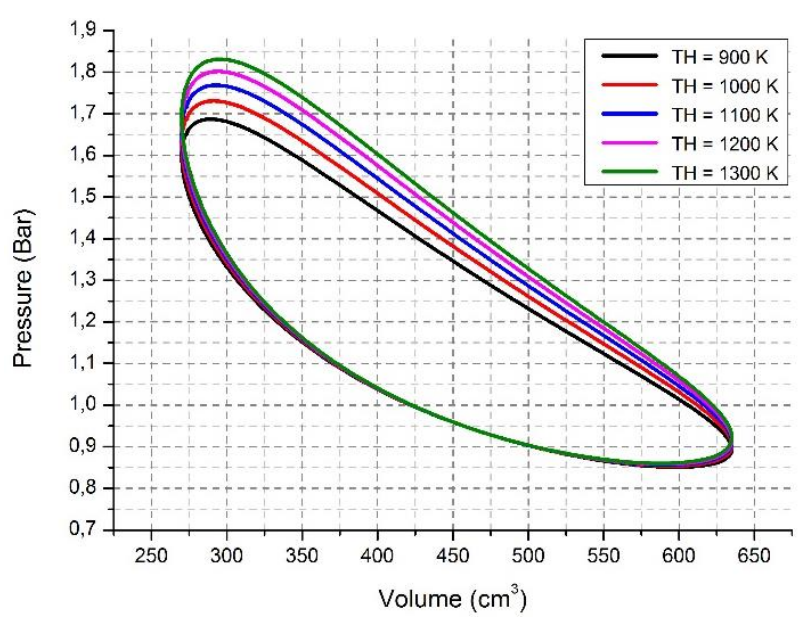

Fig. 4. Comparison of $\mathrm{P}-\mathrm{V}$ diagrams for different temperatures of slider crank drive mechanism

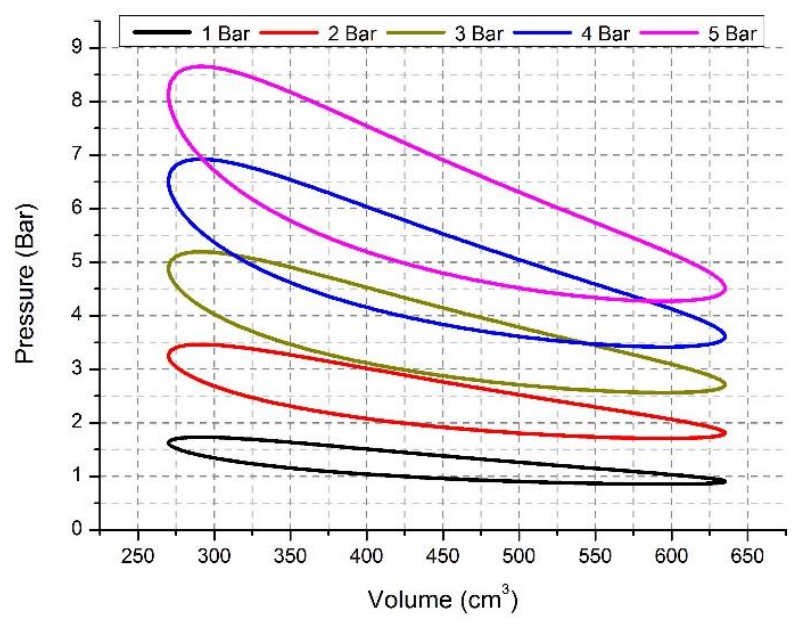

Fig. 5. Comparison of $\mathrm{P}-\mathrm{V}$ diagrams for different charge pressures of slider crank drive mechanism

Comparison of $\mathrm{P}-\mathrm{V}$ diagrams at different charge pressures, depending on volume change of Stirling engine with slider crank drive mechanism is given in Fig. 5. The mass of the working fluid varies at a certain rate as the amount of charge pressure increases. The heater temperature and the coolant temperature were kept constant respectively $1000 \mathrm{~K}$ and $300 \mathrm{~K}$ during a cycle for $1,2,3,4$, and 5 bar charge pressures. Under these conditions, cyclic work values of this engine with slider crank drive mechanism were obtained as $12.44 \mathrm{~J}, 24.88 \mathrm{~J}$, 
37.32 J, 49.76 J and 62.20 J, respectively. When the graphic and results are examined, it is determined that the net cyclic work amount performed increases in direct proportion to the charge pressure.

Comparison of $\mathrm{P}-\mathrm{V}$ diagrams at different heater temperatures, depending on volume change of Stirling engine with rhombic drive mechanism is given in Fig. 6. During the thermodynamic analyses the mass of the working fluid was kept constant at $0.000536 \mathrm{~kg}$ and coolant temperature was kept constant at $300 \mathrm{~K}$. Cyclic work values of this engine with rhombic drive mechanism were calculated as $10.66 \mathrm{~J}, 11.61 \mathrm{~J}, 12.42 \mathrm{~J}$, $13.12 \mathrm{~J}$ and $13.73 \mathrm{~J}$, for different heater temperature, respectively. The net work output is thus obtained from Eq. (2).

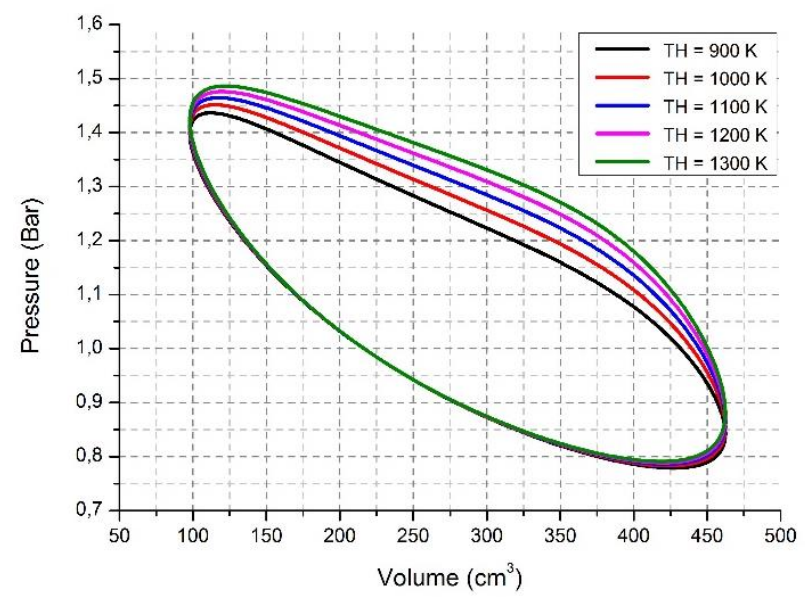

Fig. 6. Comparison of $\mathrm{P}-\mathrm{V}$ diagrams for different temperatures of rhombic drive mechanism

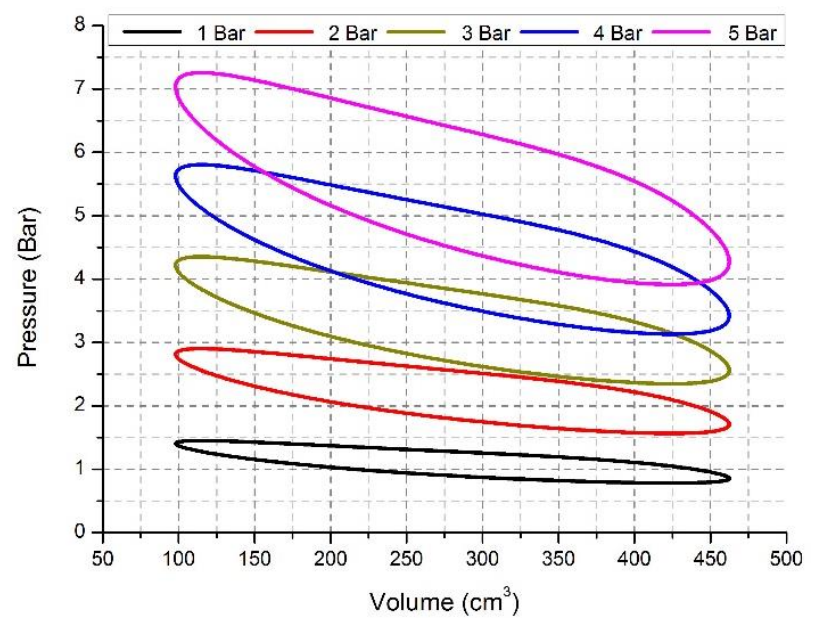

Fig. 7. Comparison of $\mathrm{P}-\mathrm{V}$ diagrams for different charge pressures of rhombic drive mechanism

Comparison of $\mathrm{P}-\mathrm{V}$ diagrams at different charge pressures, depending on volume change of Stirling engine with rhombic drive mechanism is given in Fig. 7. The mass of the working fluid varies at a certain rate as the amount of charge pressure increases. The heater temperature and the coolant temperature were kept constant respectively $1000 \mathrm{~K}$ and $300 \mathrm{~K}$ during a cycle for 1, 2, 3, 4, and 5 bar charge pressures. Under these conditions, cyclic work values of this engine with rhombic drive mechanism were obtained as $11.61 \mathrm{~J}, 23.22 \mathrm{~J}, 34.83 \mathrm{~J}, 46.44 \mathrm{~J}$ and $58.05 \mathrm{~J}$, respectively. When the graphic and results are examined, it is determined that the net cyclic work amount performed increases in direct proportion to the charge pressure.

Comparison of $\mathrm{P}-\mathrm{V}$ diagrams at different heater temperatures, depending on volume change of Stirling engine with scotch yoke drive mechanism is given in Fig. 8. During the thermodynamic analyses the mass of the working fluid was kept constant at $0.000724 \mathrm{~kg}$ and coolant temperature was kept constant at $300 \mathrm{~K}$. Cyclic work values of this engine with scotch yoke drive mechanism were calculated as $11.95 \mathrm{~J}, 13.05 \mathrm{~J}, 14.00 \mathrm{~J}, 14.82 \mathrm{~J}$ and $15.55 \mathrm{~J}$, for different heater temperature, respectively. The net work output is thus obtained from Eq. (2).

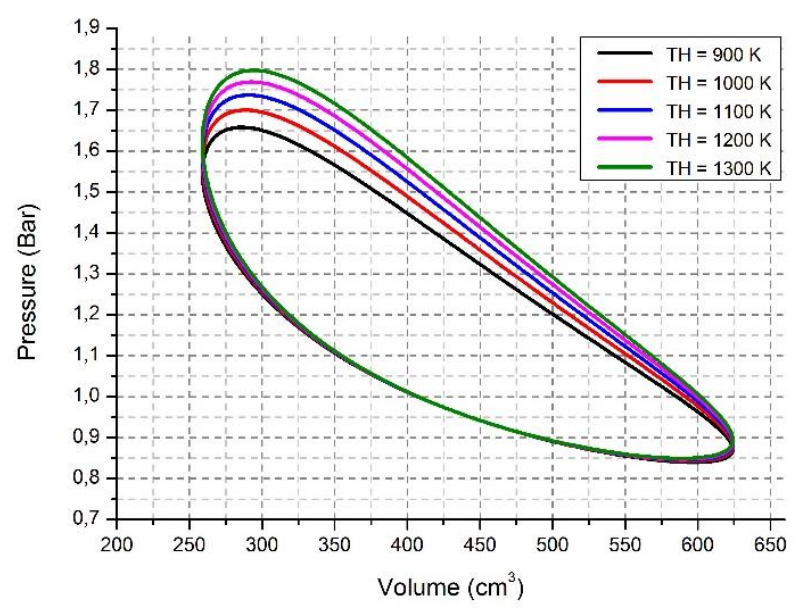

Fig. 8. Comparison of $\mathrm{P}-\mathrm{V}$ diagrams for different temperatures of scotch yoke drive mechanism

Comparison of $\mathrm{P}-\mathrm{V}$ diagrams at different charge pressures, depending on volume change of Stirling engine with scotch yoke drive mechanism is given in Fig. 9. The mass of the working fluid varies at a certain rate as the amount of charge pressure increases. The heater temperature and the coolant temperature were kept constant respectively $1000 \mathrm{~K}$ and $300 \mathrm{~K}$ during a cycle for $1,2,3,4$, and 5 bar charge pressures. Under these conditions, cyclic work values of this engine with scotch yoke drive mechanism were obtained as $13.05 \mathrm{~J}, 26.11 \mathrm{~J}$, 39.16 J, 52.22 J and 65.27 J, respectively. When 
the graphic and results are examined, it is determined that the net cyclic work amount performed increases in direct proportion to the charge pressure.

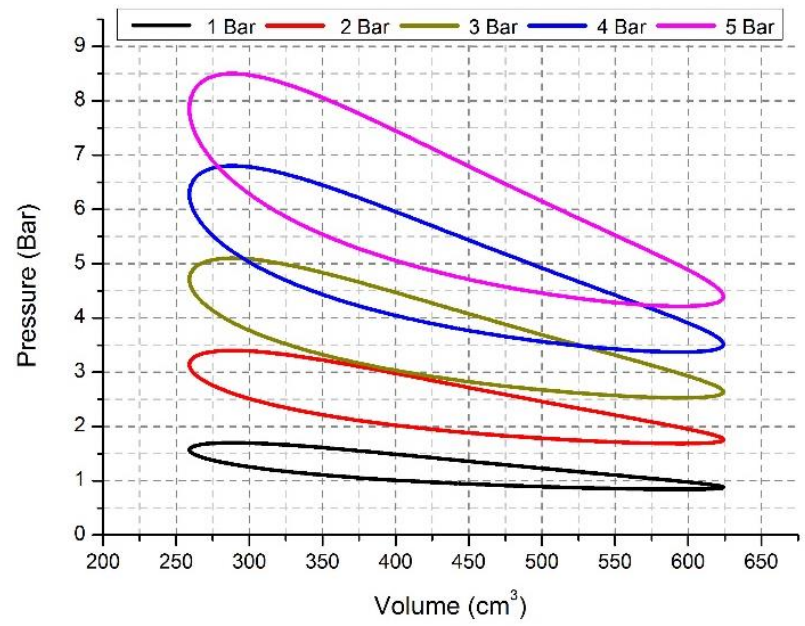

Fig. 9. Comparison of $\mathrm{P}-\mathrm{V}$ diagrams for different charge pressures of scotch yoke drive mechanism

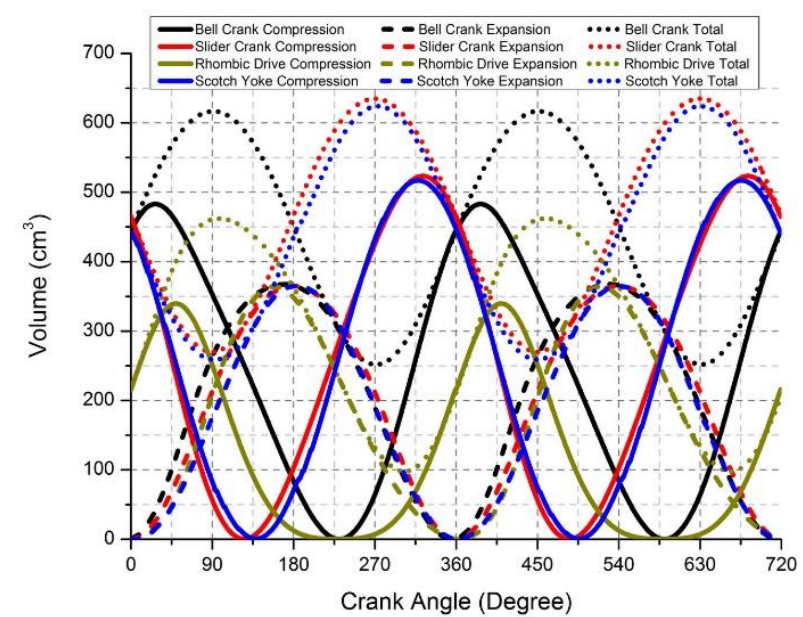

Fig. 10. The variation of volumes according to different crank angle

Four different drive mechanisms, called as bell crank, slider crank, rhombic and scotch yoke are used in beta type Stirling engines. In this study, separate kinematic analyses were made by using MSC Adams software for these four different drive mechanisms with the same swept volume in a beta type Stirling engine, and the results were compared. Thermodynamic analyses of Stirling engines with these different drive mechanisms was investigated using the isothermal analysis method. The comparison of the volume changes obtained with the MSC Adams software for bell crank, slider crank, rhombic and scotch yoke drive mechanisms are given in Fig. 10.

When Fig. 10. is analyzed it is seen that although the power piston and displacer piston have the same strokes, the compression volume and expansion volume values are different from each other. It is also seen that particularly in the rhombic drive mechanism the compression volume and the expansion volume values are close to each other. In other drive mechanisms, the compression volume value is found to be much higher than the expansion volume value. For this reason, the total volume value in the rhombic drive mechanism is lower than in the other drive mechanisms.

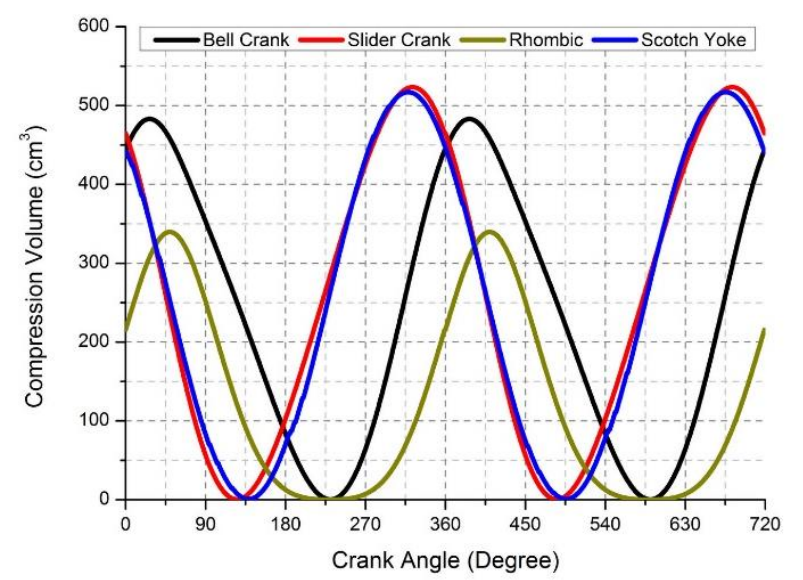

Fig. 11. The variation of compression volumes according to different crank angle

Comparison of the compression volume values obtained in the MSC Adams software for bell crank, slider crank and scotch yoke drive mechanisms are given in Fig. 11. Although these drive mechanisms have the same swept volumes, their compression volume values are different from each other. It is seen that the highest volume value in terms of compression volume was obtained with the slider crank and scotch yoke drive mechanisms. The lowest compression volume value was obtained with rhombic drive mechanism. In addition, the compression volume value stays stable at the minimum level after the crankshaft moves to $180^{\circ}$ position for nearly a period of $90^{\circ}$, which is specific to the rhombic drive mechanism. In order words, compression process occurs at a constant temperature for a duration of $90^{\circ}$. It may be clearly seen in the graphics that this value is not so stable in other drive mechanisms. Since the volume changes of the engines are higher in bell crank, slider crank and scotch yoke drive mechanisms are greater than those in the Stirling engines with rhombic drive mechanism, it was determined that the compression ratios of these engines are smaller 
than the engines with rhombic drive mechanism. For this reason the highest compression volume value was obtained with rhombic drive mechanism. The compression ratios of the engines with bell crank, slider crank, rhombic and scotch yoke drive mechanism were calculated to be $2.45,2.35,4.72$ and 2.40, respectively. Although these drive mechanisms have the same swept volumes, their compression ratios values are different from each other.

Comparison of the expansion volume changes obtained in the MSC Adams software depending on the crankshaft angle is given in Fig. 12. When the graphic is examined, it is seen that the maximum volume change values are close to each other for all mechanisms. However, it was determined that the expansion volume changes were obtained at different crankshaft angles. All the analyses were started at a state when the expansion volume was at the minimum level and when the displacer piston was at the top dead center. In this way, the results were compared better in the graphics.

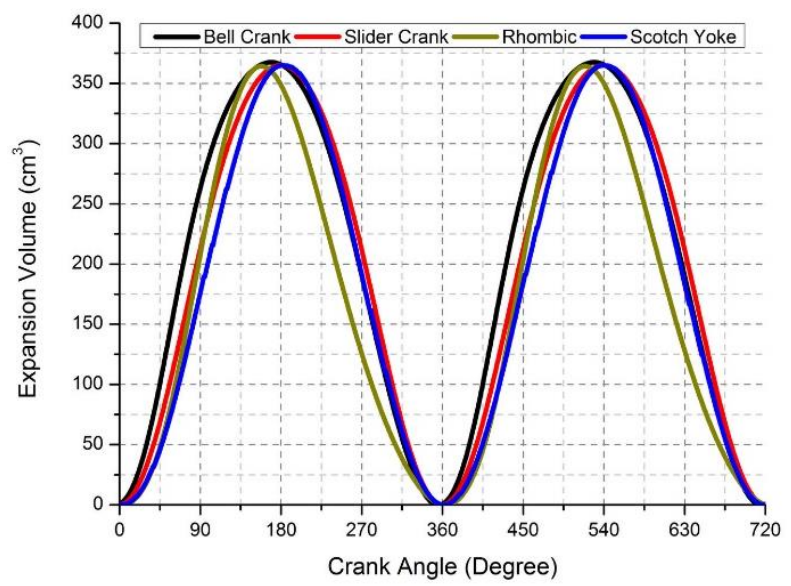

Fig. 12. The variation of expansion volumes according to different crank angle

Comparison of total volume changes depending on the crankshaft angle of different drive mechanisms are given in Fig. 13. When the results of the analyses were examined, it is clearly seen that the total volume changes of the Stirling engine with rhombic drive mechanism are lowest than the Stirling engines with other mechanisms. The reason for this is the fact that the compression volume value of the Stirling engines with rhombic drive mechanism is the lowest. It was determined that the total volume changes of the Stirling engines with other drive mechanisms are close to each other. It was also determined that the total volume change occurs at nearly the same crankshaft angles in slider crank and scotch yoke, bell crank and rhombic drive mechanisms.

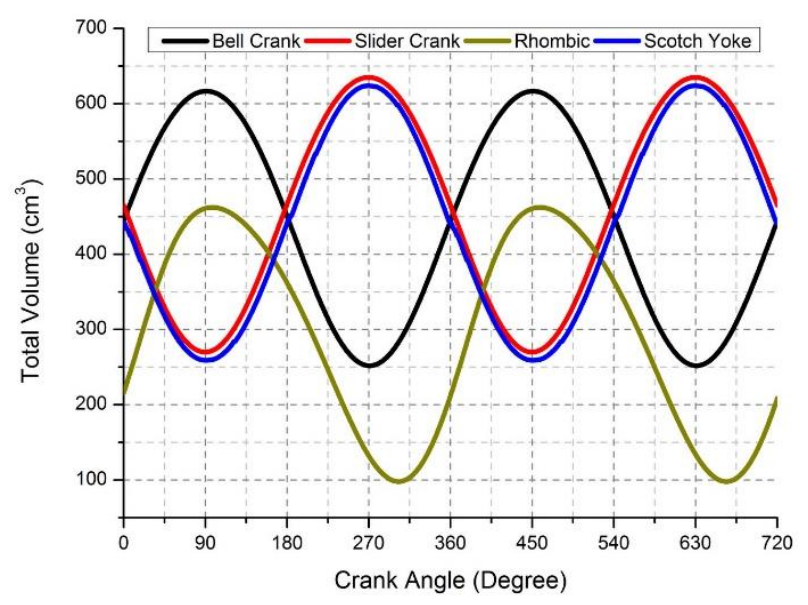

Fig. 13. The variation of total volumes according to different crank angle

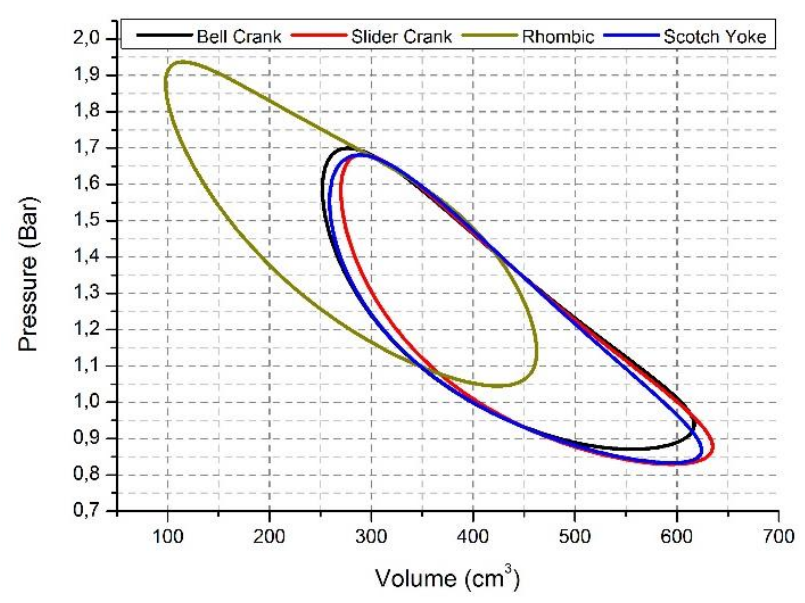

Fig. 14. Comparison of $\mathrm{P}-\mathrm{V}$ diagrams of different drive mechanisms for constant working fluid $(\mathrm{m}=0.000716 \mathrm{~kg})$

The comparison of the pressure changes depending on the crankshaft angle and on the volume change obtained as a result of the thermodynamic analyses conducted for equal amount of working fluid for bell crank, slider crank, rhombic and scotch yoke drive mechanisms is given in Fig. 14. and Fig. 15. The mass of the working fluid was kept constant at $0.000716 \mathrm{~kg}$. The heater temperature and the coolant temperature were kept constant respectively $1000 \mathrm{~K}$ and $300 \mathrm{~K}$. Under these conditions, the net work amounts obtained in one cycle time from the engines with bell crank, slider crank, rhombic and scotch yoke drive mechanism were $12.85 \mathrm{~J}, 12.09 \mathrm{~J}, 15.49 \mathrm{~J}$ and $12.91 \mathrm{~J}$, respectively. Although these drive mechanisms have the same swept volumes, their total volume values are different from each 
other. When the results of the analyses are investigated, it is clear that the total volume changes of the Stirling engines with rhombic drive mechanism are lower when compared with the Stirling engines with other drive mechanisms. For this reason, in the research conducted with working fluid of equal amount it was determined that the engines with rhombic drive mechanism generates $19.2 \%$ net work more than the other drive mechanisms.

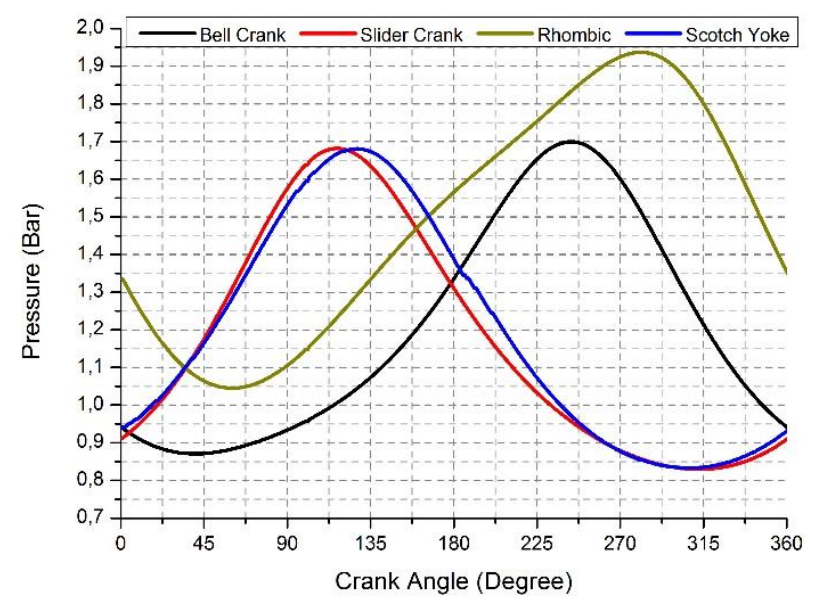

Fig. 15. The variation of pressures according to different crank angle for constant working fluid

$$
(\mathrm{m}=0.000716 \mathrm{~kg})
$$

The comparison of pressure changes depending on the compression volume and expansion volume change obtained as a result of the thermodynamic analyses made for equal amount of working fluid $(0.000716 \mathrm{~kg})$ for bell crank, slider crank, rhombic and scotch yoke drive mechanisms is given in Fig. 16. and Fig. 17.

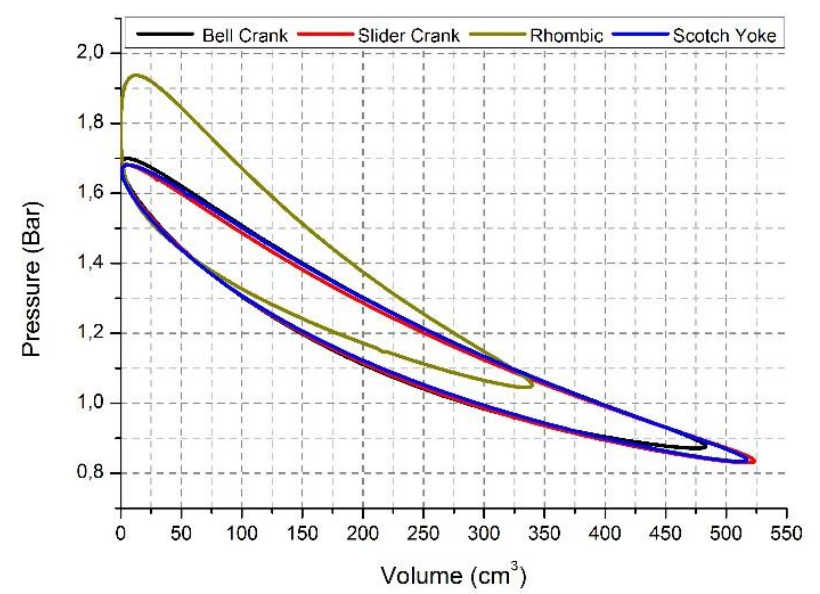

Fig. 16. Comparison of $\mathrm{P}-\mathrm{V}$ diagrams of compression volumes for constant working fluid $(\mathrm{m}=0.000716 \mathrm{~kg})$

The comparison of the pressure changes depending on the crankshaft angle and on the volume change obtained as a result of the thermodynamic analyses conducted for the same charge pressure value working fluid for bell crank, slider crank, rhombic and scotch yoke drive mechanisms is given in Fig. 18. and Fig. 19.

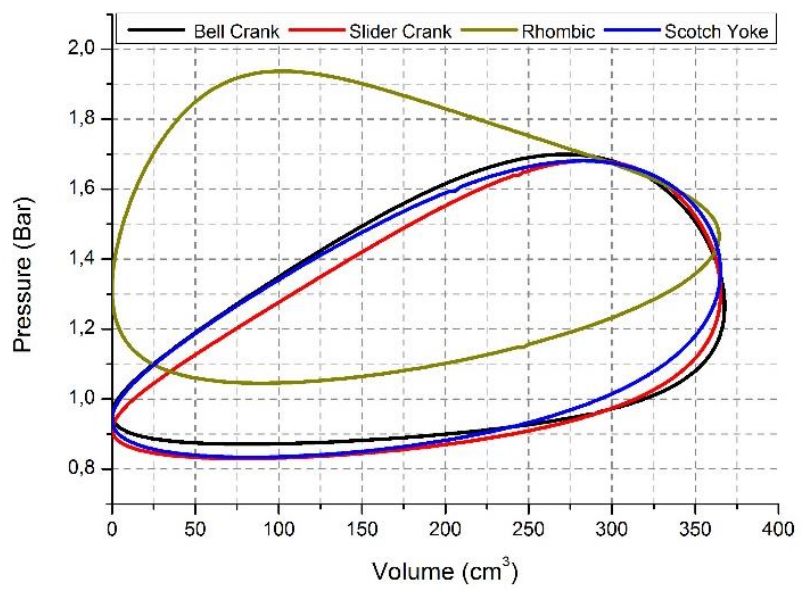

Fig. 17. Comparison of $\mathrm{P}-\mathrm{V}$ diagrams of expansion volumes for constant working fluid $(\mathrm{m}=0.000716 \mathrm{~kg})$

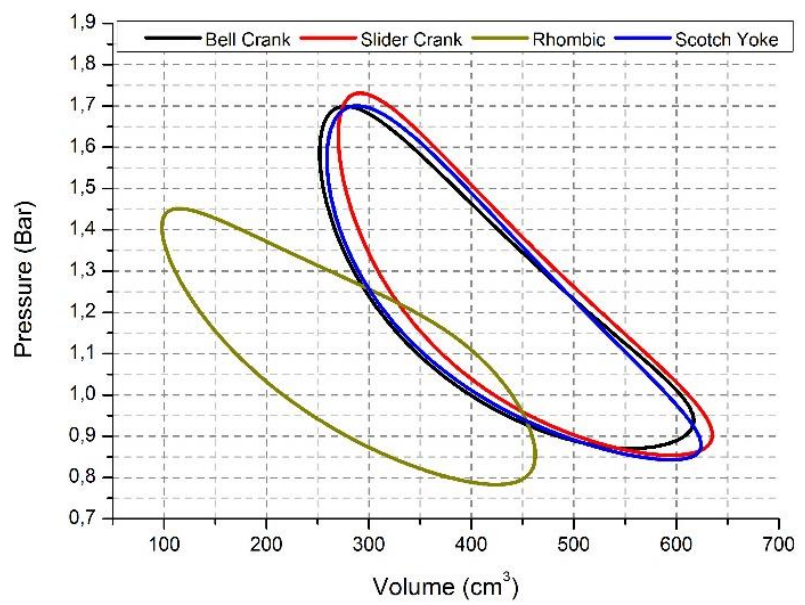

Fig. 18. Comparison of $\mathrm{P}-\mathrm{V}$ diagrams of different drive mechanisms for working fluid with same charge pressure (1 Bar)

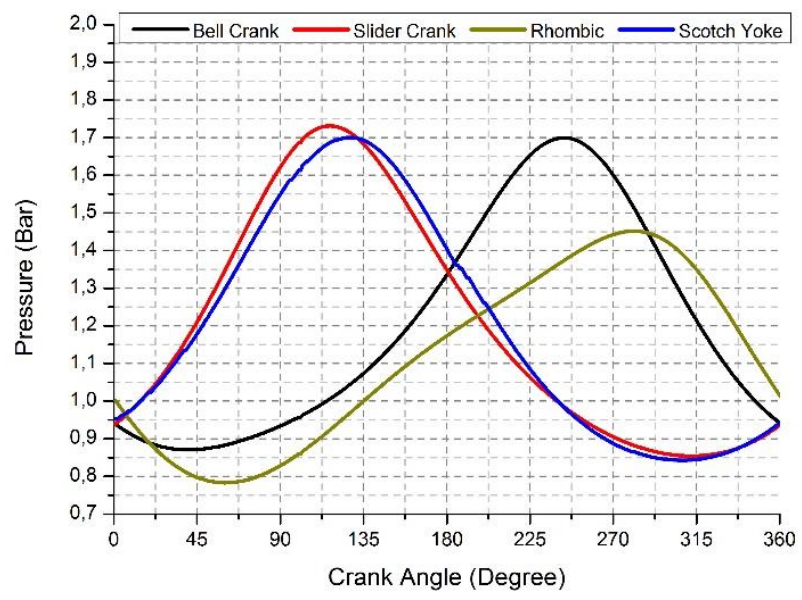

Fig. 19. The variation of pressures according to different crank angle for working fluid with same charge pressure (1 Bar) 
The mass of the working fluid changes at certain amounts as much as the charge pressure amount. The masses of the working fluid used in 1 bar charge pressure from the engines with bell crank, slider crank, rhombic and scotch yoke drive mechanism were $0.000716 \mathrm{~kg}, 0.000737$ $\mathrm{kg}, 0.000536 \mathrm{~kg}$ and $0.000724 \mathrm{~kg}$, respectively. The heater temperature and the coolant temperature were kept constant $1000 \mathrm{~K}$ and 300 $\mathrm{K}$, respectively. Under these conditions, the net work amounts obtained in one cycle time from the engines with bell crank, slider crank, rhombic and scotch yoke drive mechanism were $12.85 \mathrm{~J}, 12.44 \mathrm{~J}, 11.61 \mathrm{~J}$ and $13.05 \mathrm{~J}$, respectively. When the results of the analyses are considered it is clearly understood that according to the analyses made for the working fluid at the same charge pressure (1 Bar), the lowest amount of net work is obtained from the Stirling engine with rhombic drive mechanism. The reason for this may stem from the fact that the total volume change of this engine is lower than that of the Stirling engines with other drive mechanisms.

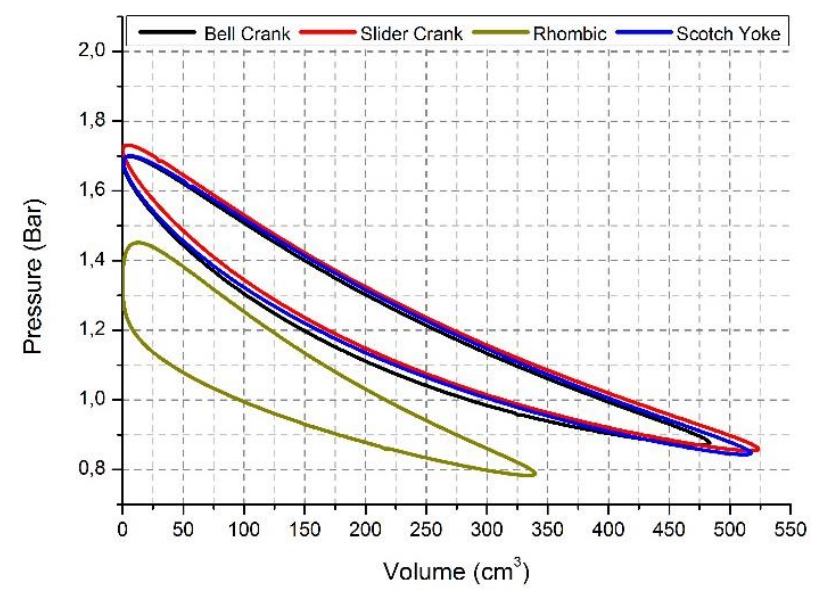

Fig. 20. Comparison of P-V diagrams of compression volumes for working fluid with same charge pressure (1 Bar)

The comparison of the pressure changes depending on the compression volume and expansion volume changes obtained as a result of thermodynamic analyses made for the same charge pressure value working fluid for bell crank, slider crank, rhombic and scotch yoke drive mechanisms is given in Fig. 20. and Fig. 21.

Comparison of the position changes of the power piston top points obtained in MSC Adams software depending on the crankshaft angle is given in Fig. 22. When the graphic is examined, it is seen that the stroke size of the power piston is $60 \mathrm{~mm}$ for all mechanisms. The reason why the power piston top heights are different are the differences among the drive mechanisms.

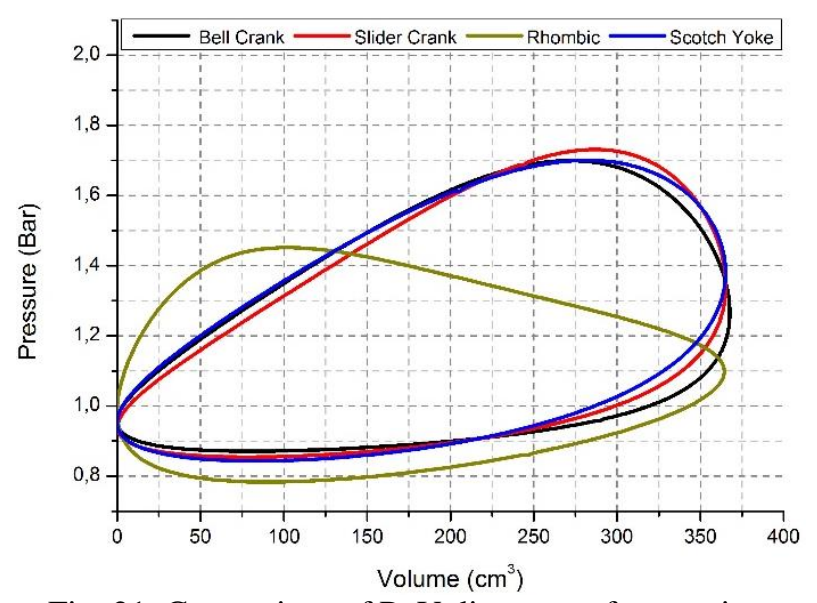

Fig. 21. Comparison of $\mathrm{P}-\mathrm{V}$ diagrams of expansion volumes for working fluid with same charge pressure (1 Bar)

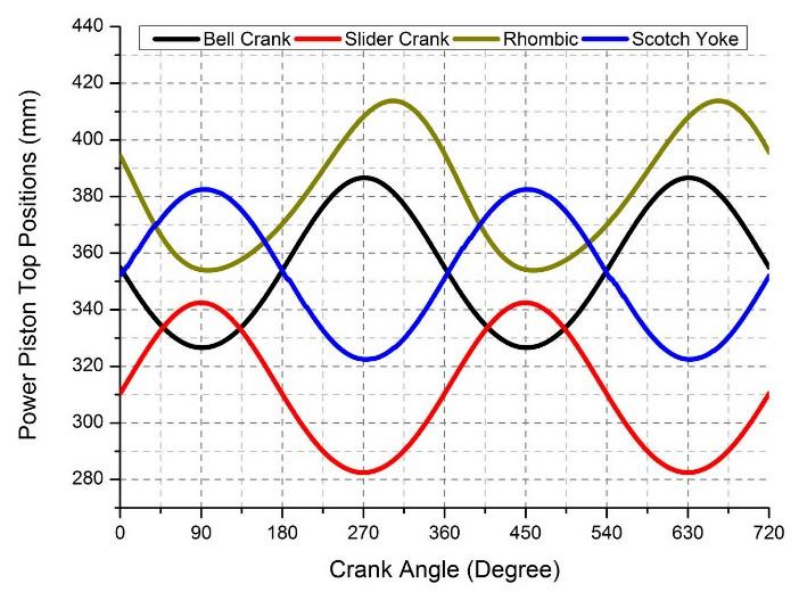

Fig. 22. The variation of power piston top positions according to different crank angle

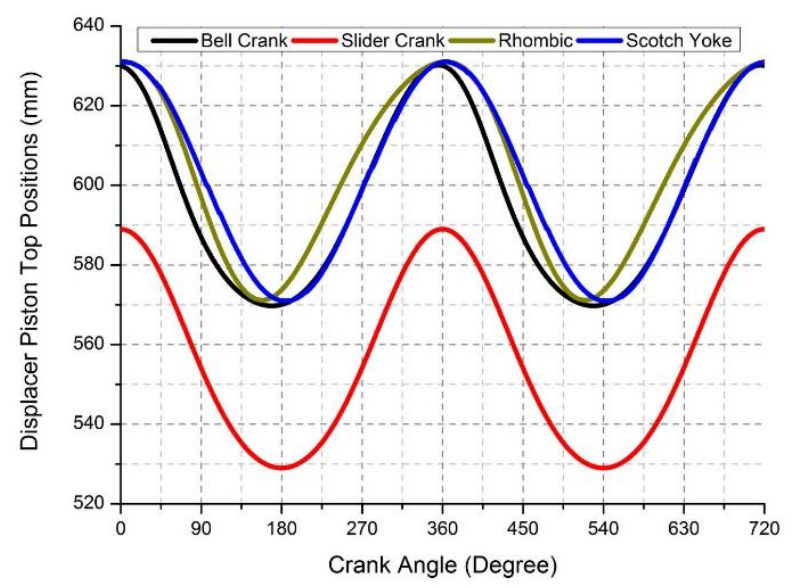

Fig. 23. The variation of displacer piston top positions according to different crank angle

Comparison of the changes in the top points of the displacer piston depending on the crankshaft angle, which was obtained in the MSC Adams software, is given in Fig. 23. When the graphic 
is examined, it is seen that the stroke size of the displacer piston is $60 \mathrm{~mm}$ for all drive mechanisms. The changes of the top heights of the displacer piston occur nearly at the same crankshaft angle.

\section{Conclusions}

In this study, thermodynamic analyses of bell crank, slider crank, rhombic and scotch yoke drive mechanisms were performed under the same conditions for a beta type Stirling engine with a swept volume of $365 \mathrm{~cm}^{3}$. As a result of the conducted analyses, the following conclusions may be made for bell crank, slider crank, rhombic and scotch yoke drive mechanisms.

- Although bell crank, slider crank, rhombic and scotch yoke drive mechanisms have the same swept volumes, their compression volume values are different from each other. In terms of compression volume values, the highest value was achieved in slider crank and scotch yoke drive mechanisms. The lowest compression volume value was achieved with the rhombic drive mechanism.

- It was determined that the compression volume and expansion volume values are close to each other, which is specific to rhombic drive mechanism. In addition, the compression volume value remains stable at minimum value after the $180^{\circ}$ position of the crankshaft for a duration of $90^{\circ}$, which is specific for this mechanism. In other words, the compression process occurs at a constant temperature for a duration of $90^{\circ}$. It is clearly seen in the graphics that these values are not stable in other drive mechanisms.

- It was determined that the volume changes of the scotch yoke and slider crank drive mechanisms were nearly very close to each other.

- The net work amounts obtained as a result of the thermodynamic analyses made for the working fluid value of the equal amount $0.000716 \mathrm{~kg}$ for bell crank, slider crank, rhombic and scotch yoke drive mechanisms are $12.85 \mathrm{~J}, 12.09 \mathrm{~J}, 15.49 \mathrm{~J}$ and $12.91 \mathrm{~J}$, respectively. In the analyses, the net work amount obtained during one cycle time from an engine with rhombic drive mechanism generates $19.2 \%$ net work more than the engines with other drive mechanisms.
- $\quad$ The mass of the working fluid changes at certain amounts as much as the charge pressure amount. The masses of the working fluid used in 1 bar charge pressure from the engines with bell crank, slider crank, rhombic and scotch yoke drive mechanism were $0.000716 \mathrm{~kg}$, $0.000737 \mathrm{~kg}, 0.000536 \mathrm{~kg}$ and $0.000724 \mathrm{~kg}$, respectively. The net work amounts obtained as a result of the thermodynamic analyses made for the same charge pressure value in bell crank, slider crank, rhombic and scotch yoke drive mechanisms are $12.85 \mathrm{~J}, 12.44 \mathrm{~J}$, $11.61 \mathrm{~J}$ and $13.05 \mathrm{~J}$, respectively. The lowest net work amount obtained during one cycle time in the analyses made for the working fluid under the same charge pressure is obtained from Stirling engine with rhombic drive mechanism.

- It was determined that the net work amounts are close to each other obtained in both thermodynamic analyses made for the equal amount of working fluid and for the same charge pressure values in bell crank, slider crank and scotch yoke drive mechanisms.

- The compression ratios of the engines with bell crank, slider crank, rhombic and scotch yoke drive mechanism were calculated to be $2.45,2.35,4.72$ and 2.40 , respectively. Although these drive mechanisms have the same swept volumes, their compression ratios values are different from each other.

\section{Nomenclature}

$\begin{array}{ll}A D A M S & \begin{array}{l}\text { automatic dynamic analysis of } \\ \text { mechanical system }\end{array} \\ C F D & \begin{array}{l}\text { computational fluid dynamics } \\ \text { mass of working fluid }(\mathrm{kg})\end{array} \\ M & \begin{array}{l}\text { Microsoft software } \\ \text { corporation } \\ \text { pressure (Bar) }\end{array} \\ P & \text { pressures at every one degree } \\ P_{l}, P_{2}, P_{3}, & \text { of crankshaft (Bar) } \\ P_{4} & \text { gas constant }(\mathrm{J} / \mathrm{kgK}) \\ R & \text { temperature }(\mathrm{K}) \\ T & \text { hot reservoir temperature }(\mathrm{K}) \\ T_{H} & \text { cold reservoir temperature }(\mathrm{K}) \\ T_{C} & \text { volume }\left(\mathrm{cm}^{3}\right) \\ V & \text { volumes at every one degree } \\ V_{l}, V_{2}, V_{3}, & \text { of crankshaft }\left(\mathrm{cm}^{3}\right) \\ V_{4} & \text { work }\left(\mathrm{J} / \mathrm{cycle}^{3}\right) \\ \mathrm{W} & \end{array}$




\section{Appendix A.}

Table A.1 Properties of beta type Stirling engines in the literature

\begin{tabular}{|c|c|c|c|c|c|c|c|}
\hline \multirow[b]{2}{*}{ Name of authors } & \multicolumn{7}{|c|}{ Properties } \\
\hline & Year & $\begin{array}{l}\text { Power } \\
\text { (W) }\end{array}$ & $\begin{array}{c}\text { Drive } \\
\text { Mechanism }\end{array}$ & $\begin{array}{l}\text { Swept } \\
\text { Volume } \\
\left(\mathrm{cm}^{3}\right)\end{array}$ & $\begin{array}{c}\text { Heater } \\
\text { Temperature } \\
\text { (K) }\end{array}$ & $\begin{array}{l}\text { Working } \\
\text { Fluid }\end{array}$ & $\begin{array}{l}\text { Experimental } \\
\text { Theoretical }\end{array}$ \\
\hline Toda et al. [45] & 1995 & - & Scotch yoke & - & - & Air & Exp. \\
\hline Iwamoto et al. [46] & 1997 & $300 \mathrm{~W}$ & Scotch yoke & - & $373 \mathrm{~K}$ & Air & Exp. \\
\hline Hirata et al. [47] & 1997 & $74 \mathrm{~W}$ & Scotch yoke & - & $973 \mathrm{~K}$ & Helium & Exp. and Theo. \\
\hline Çınar et al. [27] & 2005 & $5.98 \mathrm{~W}$ & Slider crank & 192 & $1273 \mathrm{~K}$ & Air & Exp. \\
\hline Eldesouki Eid [32] & 2009 & - & $\begin{array}{l}\text { Rhombic } \\
\text { Bell crank }\end{array}$ & 233 & $977 \mathrm{~K}$ & Helium & Theo. \\
\hline Karabulut et al. [21] & 2009 & - & $\begin{array}{c}\text { and } \\
\text { Rhombic }\end{array}$ & - & - & - & Theo. \\
\hline Cheng et al. [33] & 2010 & $16.8 \mathrm{~W}$ & Rhombic & - & $800 \mathrm{~K}$ & - & Theo. \\
\hline Cheng et al. [28] & 2011 & - & Slider crank & - & & - & Theo. \\
\hline Gheith et al. [51] & 2011 & $88 \mathrm{~W}$ & Slider crank & - & $808 \mathrm{~K}$ & Air & Exp. and Theo. \\
\hline Sripakagorn et al. [48] & 2011 & $95.4 \mathrm{~W}$ & $\begin{array}{l}\text { Scotch yoke } \\
\text { Slider crank }\end{array}$ & 165 & $773 \mathrm{~K}$ & Air & Exp. \\
\hline Shendage et al. [39] & 2011 & - & $\begin{array}{c}\text { and } \\
\text { Rhombic }\end{array}$ & - & - & - & Theo. \\
\hline Cheng et al. $[34,35]$ & 2012 & - & Rhombic & - & - & - & Theo. \\
\hline Zhang et al. [52] & 2012 & - & Rhombic & - & - & - & Theo. \\
\hline Cheng et al. [36] & 2013 & $390 \mathrm{~W}$ & Rhombic & 135 & $1123 \mathrm{~K}$ & Helium & Exp. and Theo. \\
\hline Antonio, et al. [53] & 2014 & - & Slider crank & - & - & - & Theo. \\
\hline Cheng C. et al. [54] & 2014 & - & Rhombic & 135 & $900-1100 \mathrm{~K}$ & Helium & Theo. \\
\hline Salazar et al. [55] & 2014 & - & $\begin{array}{l}\text { Rhombic } \\
\text { Bell crank }\end{array}$ & - & - & - & Theo. \\
\hline Solmaz et al. [40] & 2014 & - & $\begin{array}{c}\text { and } \\
\text { Rhombic }\end{array}$ & - & $850 \mathrm{~K}$ & - & Theo. \\
\hline Chen et al. [56] & 2015 & - & Rhombic & - & - & - & Theo. \\
\hline Zainudin et al. [57] & 2015 & - & Rhombic & - & - & - & Theo. \\
\hline Araoz et al. [29] & 2015 & $832 \mathrm{~W}$ & Slider crank & - & $1387 \mathrm{~K}$ & Nitrogen & Exp. and Theo. \\
\hline Ni et al. [58] & 2016 & $\begin{array}{l}165 \mathrm{~W} \\
139 \mathrm{~W}\end{array}$ & Rhombic & - & - & $\begin{array}{l}\text { Helium } \\
\text { Nitrogen }\end{array}$ & Exp. and Theo. \\
\hline Aksoy et al. [41] & 2016 & - & $\begin{array}{c}\text { Slider crank } \\
\text { and } \\
\text { Rhombic }\end{array}$ & - & $1500 \mathrm{~K}$ & Air & Theo. \\
\hline Barreto et al. [30] & 2017 & - & Slider crank & - & - & Helium & Theo. \\
\hline Xiao et al. [59] & 2017 & - & Rhombic & - & - & Helium & Theo. \\
\hline Abuelyamen et al. [60] & 2017 & - & Rhombic & - & - & - & Theo. \\
\hline
\end{tabular}

\section{References}

1. N. Abas, A. Kalair, N. Khan, Review of fossil fuels and future energy technologies, Futures, 69, 31-49, (2015).

2. BP, Statistical Review of World Energy, (2016).

3. A.A.A. Agll, Y.M. Hamad, T.A. Hamad, J.W. Sheffield, Study of energy recovery and power generation from alternative energy source, Case Studies in Thermal Engineering, 4, 92-98, (2014).

4. S. Shafiee, E. Topal, When will fossil fuel reserves be diminished? Energy Policy, 37, 181-189, (2009).

5. K. Kaygusuz, Energy for sustainable development: A case of developing countries,
Renewable and Sustainable Energy Reviews, 16, 1116-1126, (2012).

6. G. Walker, Stirling engines, United States by Oxford University Press, (1980).

7. R. Stirling, Stirling air engine and the heat regenerator, Patent No: 4081, (1816).

8. D. Erol, H. Yaman, B. Doğan, A review development of rhombic drive mechanism used in the Stirling engines, Renewable and Sustainable Energy Reviews, 78, 1044-1067, (2017).

9. C. Çınar, F. Aksoy, D. Erol, The effect of displacer material on the performance of a low temperature differential Stirling engine, International Journal of Energy Research, 36, 911-917, (2012). 
10. H.D. Brey, H. Rinia, F.L.V. Weenen, Fundamentals for the development of the philips air engine, Philips Technical Review, 9, 97-104, (1947).

11. R.J. Meijer, The Philips hot gas engine with rhombic drive mechanism, Philips Technical Review, 20, 245-276, (1959).

12. R.J. Meijer, Philips Stirling engine activities, SAE Technical Paper, 650004, (1965) 13. G. Walker, O.R. Fauvel, G. Reader, The literature of stirling engines, in: Energy Conversion Engineering Conference, Proceedings of the 24th Intersociety, (1989).

14. G. Schmidt, Theorie der Lehmann'schen Calorischen Maschine (Theory of Lehmann's caloric machine), Zeitschrift des Vereins deutscher Ingenieure, 15, (1871).

15. A.J. Organ, Thermodynamics and gas dynamics of the stirling cycle machine, Cambridge University Press, New York, (1992).

16. T. Finkelstein, A new isothermal theory for Stirling machine analysis and a volume optimization using the concept of ancillary and tidal domains, in: Proceedings of the Institution of Mechanical Engineers, Part C: Journal of Mechanical Engineering Science, 212, 225-236, (1998).

17. I. Delyova, D. Hroncova, P. Frankovsky, E. Dzurisova, F. Rakay, Kinematic analysis of crank rocker mechanism using MSC Adams/View, Applied Mechanics and Materials, 611, 90-97, (2014).

18. J. Doane, Machine analysis with computer applications for mechanical engineers, John Wiley and Sons, (2015).

19. T. Finkelstein, A.J. Organ, Air engines the history science and reality of the perfect engine, The American Society of Mechanical Engineers, New York, (2004).

20. C.M. Hargreaves, The philips stirling engine, Elsevier, New York, (1991).

21. H. Karabulut, F. Aksoy, E. Öztürk, Thermodynamic analysis of a beta type Stirling engine with a displacer driving mechanism by means of a lever, Renewable Energy, 34, 202208, (2009).

22. H. Karabulut, H.S. Yücesu, C. Çınar, F. Aksoy, An experimental study on the development of a beta type Stirling engine for low and moderate temperature heat sources, Applied Energy, 86, 68-73, (2009).

23. C.S. Sharma, K. Purohit, Theory of mechanisms and machines, Prentice-Hall of India Private Limited, New Delhi, (2006).

24. G.S. Sawhney, Fundamentals of mechanical engineering: Thermodynamics, mechanics, theory of machines, strength of materials and fluid dynamics, PHI Learning Private Limited, (2015).

25. K.J. Waldron, G.L. Kinzel, S.K. Agrawal, Kinematics, dynamics, and design of machinery, Wiley, (2016).

26. D. Hroncova, M. Binda, P. Sarga, F. Kicak, Kinematical analysis of crank slider mechanism using MSC Adms/View, Procedia Engineering, 48, 213-222, (2012).

27. C. Çınar, H.S. Yücesu, T. Topgül, M. Okur, Beta type Stirling engine operating at atmospheric pressure, Applied Energy, 81, 351357, (2005).

28. C.H. Cheng, Y.J. Yu, Dynamic simulation of a beta type Stirling engine with cam drive mechanism via the combination of the thermodynamic and dynamic models, Renewable Energy, 36, 714-725, (2011).

29. J.A. Araoz, M. Salomon, L. Alejo, T.H. Fransson, Numerical simulation for the design analysis of kinematic Stirling engines, Applied Energy, 159, 633-650, (2015).

30. G. Barreto, P. Canhoto, Modelling of a Stirling engine with parabolic dish for thermal to electric conversion solar energy, Energy Conversion and Management, 132, 119-135, (2017).

31. W.S. Badr, M. Fanni, A.K. AbdelRahman, S.A. Rasoul, Dynamic simulation and optimization of rhombic drive Stirling engine using MSC Adams software, Procedia Technology, 22, 754-761, (2016).

32. E. Eid, Performance of a beta configuration heat engine having a regenerative displacer, Renewable Energy, 34, 2404-2413, (2009).

33. C.H. Cheng, Y.J. Yu, Numerical model for predicting thermodynamic cycle and thermal efficiency of a beta type Stirling engine with rhombic drive mechanism, Renewable Energy, 35, 2590-2601, (2010).

34. C.H. Cheng, Y.J. Yu, Combining dynamic and thermodynamic models for dynamic simulation of a beta type Stirling engine with rhombic drive mechanism, Renewable Energy, 37, 161-173, (2012).

35. C.H. Cheng, H.S. Yang, Optimization of 
geometrical parameters for Stirling engines based on theoretical analysis, Applied Energy, 92, 395-405, (2012).

36. C.H. Cheng, H.S. Yang, L. Keong, Theoretical and experimental study of a $300 \mathrm{~W}$ beta type Stirling engine, Energy, 59, 590-599, (2013).

37. H.S. Yang, C.H. Cheng, Development of a beta type Stirling engine with rhombic drive mechanism using a modified non ideal adiabatic model, Applied Energy, 200, 62-72, (2017).

38. C.H. Cheng, Y.F. Chen, Numerical simulation of thermal and flow fields inside a 1 $\mathrm{kW}$ beta type Stirling engine, Applied Thermal Engineering, 121, 554-561, (2017).

39. D.J. Shendage, S.B. Kedare, S.L. Bapat, An analysis of beta type Stirling engine with rhombic drive mechanism, Renewable Energy, 36, 289-297, (2011).

40. H. Solmaz, H. Karabulut, Performance comparison of a novel configuration of beta type Stirling engines with rhombic drive engine, Energy Conversion and Management, 78, 627633, (2014).

41. F. Aksoy, H. Solmaz, H. Karabulut, C. Çınar, Y.Ö. Özgören, S. Polat, A thermodynamic approach to compare the performance of rhombic drive and crank drive mechanisms for a beta type Stirling engine, Applied Thermal Engineering, 93, 359-367, (2016).

42. D. Scott, New Wave, in: Popular Science, 236, 56-57, (1990).

43. V. Arakelian, J.-P.L. Baron, M. Mkrtchyan, Design of Scotch yoke mechanisms with improved driving dynamics, in: Proceedings of the Institution of Mechanical Engineers, Part K: Journal of Multi-body Dynamics, (2015).

44. T. Mang, K. Bobzin, T. Bartels, Industrial Tribology: Tribosystems, Friction, Wear and Surface Engineering, Lubrication, Wiley VCH Verlag GmbH \& Co. KGaA, (2010).

45. F. Toda, S. Iwamoto, M. Takeuchi, Development of $300 \mathrm{~W}$ class low temperature differential Stirling engine, in: Proceedings of the 7th ICSC, Tokyo, JSME, (1995).

46. S. Iwamoto, F. Toda, K. Hirata, M. Takeuchi, T. Yamamoto, Comparison of lowand high-temperature differential Stirling engines, in: Proceedings of eighth International
Stirling engine conference, 29-38, (1997).

47. K. Hirata, S. Iwamoto, F. Toda, K. Hamaguchi, Performance evaluation for a 100 W Stirling engine, in: Proceedings of 8th International Stirling Engine Conference, 19-28, (1997).

48. A. Sripakagorn, C. Srikam, Design and performance of a moderate temperature difference Stirling engine, Renewable Energy, 36, 1728-1733, (2011).

49. N.V. Orlandea, Multibody systems history of Adams, Journal of Computational and Nonlinear Dynamics, 11 (2016).

50. A.A. Shabana, An important chapter in the history of multibody system dynamics, Journal of Computational and Nonlinear Dynamics, 11 (2016).

51. R. Gheith, F. Aloui, S.B. Nasrallah, Experimental study of a beta Stirling thermal machine type functioning in receiver and engine modes, Journal of Applied Fluid Mechanics, 4, 32-42, (2011).

52. X. Zhang, Y. Ma, C.-m. Yang, L. Fu, Dynamic analysis and design of the rhombic drive of Stirling engine, Advanced Materials Research, 429, 165-171, (2012).

53. M.R. Antonio, M. Santillan, On the dynamical vs. thermodynamically performance of a beta type Stirling engine, Physica A, 409, 162-174, (2014).

54. C.H. Cheng, H.S. Yang, Optimization of rhombic drive mechanism used in beta type Stirling engine based on dimensionless analysis, Energy, 64, 970-978, (2014).

55. J.L. Salazar, W.-L. Chen, A computational fluid dynamics study on the heat transfer characteristics of the working cycle of a beta type Stirling engine, Energy Conversion and Management, 88, 177-188, (2014).

56. W.-L. Chen, K.-L. Wong, Y.-F. Chang, A numerical study on the effects of moving regenerator to the performance of a beta type Stirling engine, International Journal of Heat and Mass Transfer, 83, 499-508, (2015).

57. M.F. Zainudin, R. Abu Bakar, G.L. Ming, T. Ali, B.A. Sup, Thermodynamic cycle evaluation of rhombic drive beta configuration Stirling engine, Energy Procedia, 68, 419-428, (2015).

58. M. Ni, B. Shi, G. Xiao, H. Peng, U. Sultan, S. Wang, Z. Luo, Improved simple analytical model and experimental study of a 
$100 \mathrm{~W}$ beta type Stirling engine, Applied Energy, 169, 768-787, (2016).

59. G. Xiao, U. Sultan, M. Ni, H. Peng, X. Zhou, S. Wang, Z. Luo, Design optimization with computational fluid dynamic analysis of beta type Stirling engine, Applied Thermal Engineering, 113, 87-102, (2017).

60. A. Abuelyamen, R. Ben-Mansour, H. Abualhamayel, E.M.A. Mokheimer, Parametric study on beta type Stirling engine, Energy Conversion and Management, 145, 53-63, (2017). 